Artículo científico

(Original paper)

\title{
IMPACTS OF CHRONIC WASTING DISEASE ON A LOW DENSITY MULE DEER (ODOCOILEUS HEMIONUS) POPULATION IN THE SAN ANDRES MOUNTAINS, CHIHUAHUAN DESERT, NEW MEXICO
}

\author{
LOUIS C. BENDER ${ }^{1}$, CRistina L. RODDEN ${ }^{2}$, PAT MATHIS ${ }^{2}$, MARA E. WEISENBERGER ${ }^{3}$, OCTAVIO C. \\ ROSAS ROSAS ${ }^{4 *}$, PATRICK C. MORROW ${ }^{2}$, BROCK D. HOENES ${ }^{5}$ \\ ${ }^{1}$ Extension Animal Sciences and Natural Resources, New Mexico State University, Las Cruces, NM 88003, USA. \\ $<$ lbender@nmsu.edu> \\ ${ }^{2}$ Environmental Stewardship Division, U.S. Department of the Army, White Sands Missile Range, WSMR, NM 88002, USA. \\ <cristina.1.rodden.civ@mail.mil>; <patrick.1.mathis2.ctr@mail.mil>; <patrick.c.morrow.civ@mail.mil> \\ ${ }^{3}$ San Andres National Wildlife Refuge, Las Cruces, NM 88012, USA. <mweisenberger@blm.gov> \\ ${ }^{4}$ Colegio de Postgraduados, Campus San Luis Potosí, Iturbide No. 73, Salinas, San Luis Potosí, México. <octaviocrr@colpos.mx> \\ ${ }^{5}$ Washington Dept. of Fish and Wildlife, 600 Capitol Way N., Olympia, WA 98501, USA. <Brock.Hoenes@dfw.wa.gov> \\ *Autor de correspondencia: <octaviocrr@colpos.mx>
}

Recibido: 26/02/2018; aceptado: 29/01/2019; publicado en línea: 01/04/2019

Editor responsable: Sonia Gallina

Bender, L. C., Rodden, C. L., Mathis, P., Weisenberger, M. E., Rosas-Rosas, O. C., Morrow, P. C., Hoenes, B. D. (2019) Impacts of chronic wasting disease on a low density mule deer (Odocoileus hemionus) population in the San Andres Mountains, Chihuahuan Desert, New Mexico. Acta Zoológica Mexicana (nueva serie), 35, 1-11. https://doi.org/10.21829/azm.2019.3502203

\begin{abstract}
Chronic wasting disease (CWD), a contagious neurodegenerative disease of cervids, is becoming increasingly prevalent in the arid Southwest including the Chihuahuan Desert ecoregion. Population effects of CWD are uncertain, particularly in arid environments, as previous work has been on relatively high density deer populations in semi-arid or temperate environments. In 2002, CWD was detected in a low density mule deer (Odocoileus hemionus) population in the arid San Andres Mountains, a Chihuahuan Desert range in southern New Mexico. We determined prevalence and distribution of CWD, and mortality and movements of deer, to assess the potential impact on low density deer populations in arid environments. Repeated seasonal primarily ante-mortem sampling found stable prevalence of $0.000-0.091$, 2003-2008. Annual CWD mortality rate was $\leq 0.02$, including deer that were culled. Monitoring of adult radio-collared deer showed no dispersal movements away from home ranges, with maximum movements of $\leq 20 \mathrm{~km}$; similarly, no juveniles dispersed from maternal ranges. Distribution of infected deer was strongly related to presence of other infected deer. Annual survival rates of mule deer and population rate-of-increase suggested little effect of CWD on population-level mortality given observed prevalence. Transmission and reservoirs of CWD in the SAM were likely limited by low deer densities, patchy distribution, and environmental characteristics (i.e., low clay content of soils) unfavorable to prion persistence, characteristics that are typical of most mule deer populations in the Chihuahuan Desert ecoregion.
\end{abstract}

Key words: Chihuahuan Desert; chronic wasting disease; mule deer; New Mexico; Odocoileus hemionus; San Andres Mountains 
RESUMEN. La enfermedad crónica degenerativa (por sus siglas en inglés: CWD), una enfermedad neurodegenerativa contagiosa de los cérvidos, se está haciendo cada vez más frecuente en el suroeste árido americano incluyendo la ecoregión del desierto de Chihuahua. Los efectos de la CWD sobre poblaciones de cérvidos silvestres son inciertos, particularmente en ambientes áridos, ya que el trabajo previo ha estado en poblaciones de ciervos de densidad relativamente alta en ambientes semi-áridos o templados. En 2002, la CWD fue detectada en una población de venado bura (Odocoileus hemionus) de baja densidad en las áridas montañas de San Andrés, una región del Desierto Chihuahuense en el sur de Nuevo México. Se determinó la prevalencia y distribución de CWD, y la mortalidad y los movimientos de los venados, para evaluar su impacto potencial en poblaciones de baja densidad en ambientes áridos. En el muestreo ante-mortem previo repetido estacionalmente se encontró prevalencia estable de 0,000-0,091, 2003-2008. La tasa anual de mortalidad por CWD fue $\leq 0,02$, incluyendo venados que fueron sacrificados. El monitoreo de venados con radio-collares adultos no mostró movimientos de dispersión fuera de los rangos de origen, con movimientos máximos de $\leq 20 \mathrm{~km}$; de manera similar, no hay juveniles dispersos de los rangos maternos. La distribución de los venados infectados estaba fuertemente relacionada con la presencia de otros venados infectados. Las tasas anuales de supervivencia del venado mula y la tasa de aumento de la población sugirieron un efecto pequeño de la CWD en la mortalidad a nivel de la población dada la prevalencia observada. La transmisión y los depósitos de CWD en el SAM (Montañas San Andrés) fueron probablemente limitados por la baja densidad de los venados, su distribución irregular y las características ambientales (es decir, bajo contenido de arcilla de los suelos) desfavorables a la persistencia de priones, características típicas de la mayoría de las poblaciones de venados bura en la ecorregión del Desierto Chihuahuense.

Palabras clave: Desierto Chihuahuense; enfermedad crónico-degenerativa; venado bura; Nuevo México; Odocoileus hemionus; Montañas San Andrés

\section{INTRODUCTION}

Chronic wasting disease (CWD) is becoming increasingly widespread in the arid Southwest, including the Chihuahuan Desert ecoregion (http://www.cwd-info.org). Chronic wasting disease (CWD) is a contagious neurodegenerative disease of cervids. Although CWD results in the eventual death of infected individuals (Williams et al., 2001, 2002), the effect of CWD on populations is less certain (Miller et al., 2006, 2008; Wasserberg et al., 2009; Almberg et al., 2011; Saunders et al., 2012), and impacts and control options depend upon prevalence and mode of transmission (Miller et al., 2006; Wasserberg et al., 2009; Almberg et al., 2011; Saunders et al., 2012). Generally, management actions aimed at broad-scale population reductions or targeted animal removals in areas where CWD is established have failed to eliminate or prevent the spread of CWD (Saunders et al., 2012). Culling as a control strategy assumes that transmission is primarily direct and density dependent (Miller et al., 2006; Conner et al., 2007; Wasserberg et al., 2009), whereas much evidence supports indirect frequency dependent transmission of CWD (Miller et al., 2006; Wasserberg et al., 2009; Almberg et al., 2011; Potapov et al., 2013). Indirect transmission and long persistence of infectious prions in the environment (Miller et al., 2004) make it difficult or impossible to eliminate CWD from populations (Miller et al., 2006; Wasserberg et al., 2009; Almberg et al., 2011; Saunders et al., 2012). Management of CWD thus may depend upon disrupting transmission pathways (Miller et al., 2006), which requires understanding of ecological factors associated with presence of CWD because local environmental conditions may strongly affect probability of CWD transmission among hosts (Almberg et al., 2011; Walter et al., 2011; Saunders et al., 2012).

In the desert Southwestern USA, CWD was first detected in 2002 in a low density (ca. $\leq 1 / \mathrm{km}^{2}$; Bender et al., 2012) mule deer (Odocoileus hemionus) population in the San Andres Mountains (SAM), a Chihuahuan Desert range in south-central New Mexico. Virtually all field studies on population effects or environmental correlates of CWD have occurred in relative high density mule or white-tailed deer $(O$. virginianus) populations in the semi-arid or temperate Rocky Mountains, Canada, and the Midwestern USA 
(Saunders et al., 2012). These ecological conditions are dissimilar to the Chihuahuan Desert habitats of the Southwestern USA and Mexico, which are more arid and characterized by patchy, low density mule deer populations (Galindo-Leal, 1993; Sánchez-Rojas \& Gallina, 2000; Esparza-Carlos et al., 2011; Bender et al., 2012), complicating management based on previous work and creating uncertainty regarding the potential impact and means of control of CWD in arid environments.

In the Southwestern USA and Mexico, mule deer are a resource of significant ecological and economic importance (Galindo-Leal, 1993; Heffelfinger, 2006; Little \& Berrens, 2008; Bender et al., 2012). Because increasing mule deer populations is a priority for management agencies and private landowners in the Chihuahuan Desert ecoregion, information is needed on CWD in low density deer populations in arid Southwestern environments to develop informed management options. Our goal was to determine the population significance and identify behavioral and environmental factors associated with the presence of CWD in mule deer in the SAM. Our specific objectives included: (1) determine prevalence of CWD; (2) assess the role of CWD in mule deer mortality; and (3) assess the likelihood of spread of CWD due to mule deer movements or dispersal from CWD-positive areas.

\section{MATERIAL AND METODS}

Study area. The greater San Andres Mountains area encompasses ca. $11,000 \mathrm{~km}^{2}$ in south-central New Mexico (Fig. 1) in the Chihuahuan Desert ecoregion, including areas of San Andres National Wildlife Refuge (SANWR), White Sands Missile Range (WSMR), NASA's White Sands Test Facility, and the Jornada Experimental Range. The SAM and surrounding terrain include playas, rugged mountain peaks and canyons, rolling grasslands, sand dunes, lava flows, and scattered springs and ponds (Muldavin et al., 2000). Precipitation averages 150-300 mm annually depending upon elevation, with the bulk of moisture occurring as short, intense rainstorms from July through September. Snowfall averages $<100 \mathrm{~mm}$, is short-lived, and occurs only at high elevations. Temperatures of the area range from -23 to $41^{\circ} \mathrm{C}$. Major vegetation communities included desert and semidesert grassland, Chihuahuan desert scrub, and Great Basin conifer woodland (Muldavin et al., 2000). Other large herbivores present included oryx (Oryx gazella gazella), desert bighorn (Ovis canadensis mexicanus), javelina (Pecari tajacu), and a limited number of elk (Cervus elaphus). Livestock were present only on the periphery of our study area, and hunting of mule deer similarly occurred only on the periphery of the study area.

Mortality. We monitored survival, causes of mortality, nutritional condition, and movements of 169 ( $n=$ 21-26 adult males and 37-62 adult females annually) radio-collared deer in the SAM, December 20032009, as a component of a larger mule deer population project (see Bender et al., 2012 for detailed methods). We monitored radio-collared deer biweekly, located all mortalities, and performed a field necropsy or removed the carcass for a lab necropsy to determine cause of death (Bender et al., 2012). We also collected biological samples including obex and pharyngeal lymph nodes to help differentiate CWD from other causes-of-mortality. Last, we calculated annual mortality rates due to CWD (Heisey \& Fuller, 1985; Bender et al., 2012).

Additionally, we captured neonate and other juvenile (<1-year-old) mule deer by hand, JuneSeptember 2005-2008, and by aerial net gunning in December and March-April 2005-2008 and 2010. Juveniles were equipped with ear tag radio-transmitters (Advanced Telemetry Systems, Asanti, Minnesota, USA) and monitored for survival and movements in association with adult deer (Hoenes, 2008).

CWD sampling. We used tonsillar biopsies to detect CWD (Wolfe et al., 2002) during annual December and April captures, 2003-2008 (Bender et al., 2012). We obtained lymphoid follicle samples from immobilized deer starting at the rostral rim of the tonsillar sinus and taking 2-4 samples beginning at the rim and including the sinus using biopsy forceps with a 6-mm cup. We preserved extracted tonsillar tissue 
in $10 \%$ neutral buffered formalin and submitted samples for histopathology and immunohistochemistry (IHC) following Miller and Williams (2002).

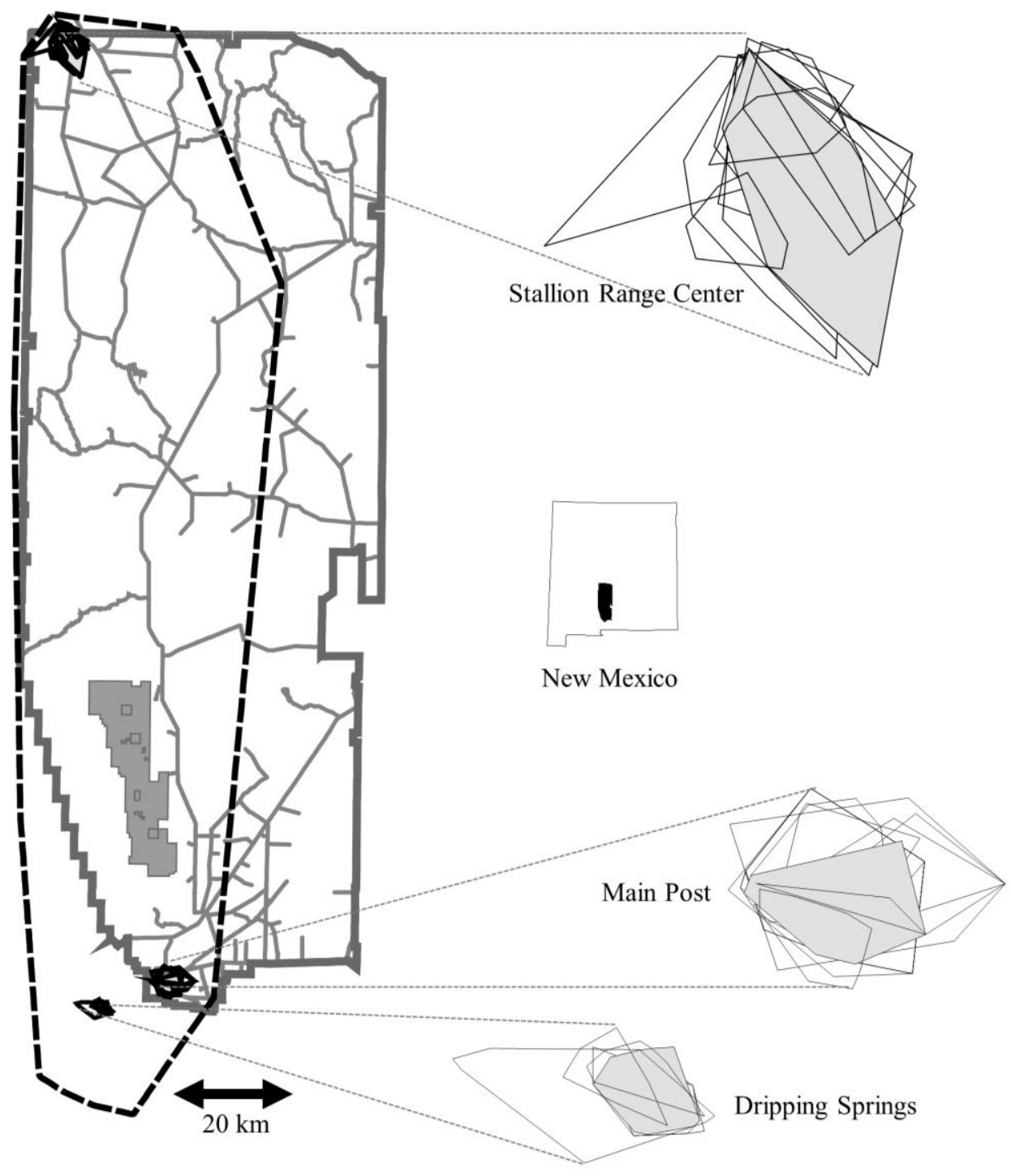

Figure 1. Composite minimum convex polygons of all locations of juvenile mule deer (solid polygon) superimposed on annual 100\% minimum convex polygons of all adult female home ranges in the Stallion Range Center, Main Post, and Dripping Springs chronic wasting disease areas, San Andres Mountains. Solid outline is White Sands Missile

Range boundary; dashed outline is $100 \%$ minimum convex polygon of all mule deer locations.

We also tested radio-collared and other deer from the SAM that died between capture periods for CWD using obex or pharyngeal lymph nodes and either the IHC or ELISA tests (Williams et al., 2001) (n $=28$, December 2003-December 2009, respectively). We calculated prevalence (i.e., the proportion of a population that is affected with a particular disease at a given time [Merriam-Webster Medical Dictionary; http://www.merriam-webster.com/medical/prevalence]) for each capture period, where prevalence $=$ number of samples testing positive for CWD/total numbers of samples. We compared prevalence among captures and sexes using Fisher's exact tests (Zar, 1996) and trend in 
prevalence using Spearman rank correlation (Zar, 1996). We calculated SE for prevalence for each capture period using the binomial approximation assuming a population size of 2000 (Zar, 1996).

Deer movements. We located radio-collared deer approximately biweekly, recorded locations with a handheld GPS, and plotted locations on GIS basemaps using ArcGIS 10.0 (ESRI, Redlands, California, USA). We constructed $100 \%$ minimum convex polygon home ranges for each deer to determine geographic extent of annual use areas (Hoenes, 2008). We defined dispersal as leaving the study area (defined as an inclusive $100 \% \mathrm{MCP}$ of all adult deer locations) and establishing a home range outside of the study area. We also determined maximum distances between any 2 locations for each deer.

We used multi-response permutation procedures (MRPP; Slauson et al., 1991) to compare geographic distributions of locations of juveniles and adult deer from their maternal home range area. We used 100\% MCP annual home ranges for all deer captured in the 3 centers of CWD (Stallion Range Center, Dripping Springs, and Main Post; Fig. 1) to determine the maximum extent of ranges of individual deer located in areas where CWD was detected. We then constructed a pooled 100\% MCP of all locations of juveniles (from capture through age 1.5) to determine extent of juvenile movements relative to maternal home ranges in areas of CWD presence. We also used MRPP to compare the spatial distributions of each CWD-positive deer with (1) spatial distributions of all other CWD-positive mule deer and (2) spatial distributions of all mule deer not testing positive for CWD in the SAM.

\section{RESULTS}

Mortality. A total of eight captured deer (seven females, one male) tested positive for CWD at capture or post-mortem (see CWD Prevalence, below). Of these, two mortalities were ultimately attributed to CWD (Bender et al., 2012). These included one radio-collared female that was proximately killed by a puma (Puma concolor), and one radio-collared female that died from unknown causes approximately six months after testing positive for CWD for a $2^{\text {nd }}$ time (she had previously tested positive two years prior to the second positive test). Of the remaining six deer that tested positive for CWD, two females (one radio-collared, one uncollared) were subsequently culled; one female's radio-collar malfunctioned and had unknown fate; and three uncollared individuals (one male, two female) had unknown fates. These individuals were censored from survival analyses in Bender et al. (2012). Thus, deaths ultimately attributable to CWD accounted for two of 72 total deer deaths (50 adult females, 22 adult males) documented during our study (Bender et al., 2012).

Of 28 total mortalities of radio-collared deer from which obex or pharyngeal lymph samples were obtained, 1 individual was positive for CWD. This adult female was the puma kill noted above. She was previously tested at capture approximately $1.5 \mathrm{y}$ prior to death and was CWD-negative at that time.

During our study (2004-2009), annual survival rates ranged from 0.74 (SE $=0.10)$ to 0.92 ( $\mathrm{SE}=$ $0.15)$ for adult males, and from $0.74(\mathrm{SE}=0.06)$ to $0.86(\mathrm{SE}=0.05)$ for adult females (Bender et al., 2012). In our general survival analysis (Bender et al., 2012), we did not discriminate between disease-related mortality factors when estimating cause-specific mortality rates. Separating the disease-related causes-ofmortality in Bender et al. (2012), CWD-specific annual mortality rate averaged 0.01 (range $=0.00-0.02 ; n$ $=$ six years) for females and 0.00 for males. If deer that tested positive for CWD but were censored from our general survival analysis (Bender et al., 2012) were included and treated as mortalities the month following capture or when culled, mean CWD-specific annual mortality rate increased to 0.02 (range = $0.00-0.07$ ) for females and 0.01 (range $=0.00-0.04$ ) for males.

CWD prevalence. We captured a total of 445 adult mule deer, including 226 different individuals and 219 recaptures. We performed a total of 364 biopsies, of which $>251$ resulted in extraction of tonsillar tissue 
with successful extraction ranging from $65-96 \%$ per capture. Seven mule deer (including the adult female which tested positive in both December 2005 and December 2007) were CWD-positive, for a prevalence of 0.000-0.091 among captures (Table 1). Mean prevalence of CWD was 0.025 (SE $=0.010$ ) among all captures (Table 1). Prevalence among capture periods did not differ (Fischer's exact $P=0.492$ ), nor did prevalence between males and females $(0.011$ v. 0.031 ; Fischer's exact $P=0.314)$ based on capture samples only, all project deer ( 0.010 v. 0.034 ; Fischer's exact $P=0.224)$, or all deer sampled in the SAM $(0.033 \mathrm{v}$. 0.049 ; Fischer's exact $P=0.481$; this included targeted removals of deer that appeared to be "sick"). There was no trend in prevalence over captures $\left(r_{\mathrm{s}}=-0.200 ; P=0.548\right)$.

Post-mortem tests of 28 project deer that died between capture periods resulted in one additional CWD-positive deer identified in June 2006. Including these deer, observed prevalence of CWD ranged from $0.000-0.079 \%$ (Table 1), with a mean among collection periods of $0.025(\mathrm{SE}=0.010)$.

Table 1. Numbers of deer sampled (No. Sampled), numbers of successful extraction of tonsillar tissue (No. Extracted), number of deer testing positive (No. Positive), and prevalence (No. Positive / No. Extracted) (SE) of chronic wasting disease in mule deer inhabiting the San Andres Mountains. Also shown is prevalence (SE) including all deer sampled (this includes mortalities, hunter harvest, culled deer, deer-vehicle collisions, etc., in addition to samples collected during captures).

\begin{tabular}{|c|c|c|c|c|c|}
\hline \multirow[b]{2}{*}{ Capture } & \multicolumn{4}{|c|}{ Tonsillar tissue } & \multirow{2}{*}{$\begin{array}{c}\text { All tissue } \\
\text { Prevalence }\end{array}$} \\
\hline & No. Sampled & No. Extracted & No. Positive & Prevalence & \\
\hline Dec 2003 & 34 & 23 & 0 & $0.000(0.000)^{1}$ & $0.000(0.000)$ \\
\hline Apr 2004 & 29 & $?^{2}$ & 0 & $0.000(0.000)$ & $0.000(0.000)$ \\
\hline Dec 2004 & 55 & 36 & 2 & $0.056(0.038)$ & $0.053(0.036)$ \\
\hline Apr 2005 & 50 & 33 & 3 & $0.091(0.051)$ & $0.079(0.043)$ \\
\hline Dec 2005 & 33 & 28 & 1 & $0.036(0.035)$ & $0.033(0.032)$ \\
\hline Apr 2006 & 36 & 31 & 1 & $0.032(0.031)$ & $0.026(0.026)$ \\
\hline Dec 2006 & 46 & 36 & 0 & $0.000(0.000)$ & $0.023(0.023)^{3}$ \\
\hline Apr 2007 & 18 & 10 & 0 & $0.000(0.000)$ & $0.000(0.000)$ \\
\hline Dec 2007 & 41 & 32 & $1^{4}$ & $0.031(0.031)$ & $0.031(0.031)$ \\
\hline Apr 2008 & 23 & 22 & 0 & $0.000(0.000)$ & $0.000(0.000)$ \\
\hline Mean & --- & --- & --- & $0.025(0.010)$ & $0.025(0.010)$ \\
\hline
\end{tabular}

${ }^{1}$ Binomial SE for capture periods based on estimated population size of 2000.

${ }^{2}$ Only data on number of positive tests available.

${ }^{3}$ Includes 1 deer from post-mortem sampling.

${ }^{4}$ Recapture of an adult female that initially tested positive in Dec 2005.

Deer movements. No radio-collared deer emigrated from the SAM. Maximum spread of movements (i.e., maximum distance between any two location points) was $<20 \mathrm{~km}$ for bucks and $<15 \mathrm{~km}$ for does.

We captured and radio-tagged 18, 37, 26, and 18 neonates, 2005-2008, respectively. We also captured additional six to nine-month-old juveniles in December $2007(n=6)$, April $2008(n=5)$, and March-April $2010(n=7)$. A total of ten, ten, seven, eight, and seven juveniles survived through age 1.5, 2005-2009, and none of these 42 juveniles dispersed from the immediate area of their maternal home range (Fig. 1) nor did the geographic distribution of their locations differ from adult deer in their maternal home range area $(P \geq 0.896)$.

We identified 13 positive test locations of CWD (includes project deer and all other deer tested from the SAM, including hunter harvests and targeted culls) associated with three geographic areas, the Main Post/Headquarters and Stallion Range Center on WSMR, and Dripping Springs Recreational Area on Bureau of Land Management ownership, immediately across the Organ Range from Main Post (Fig. 1). Distributions of all CWD-positive deer were significantly related $(P \leq 0.0004)$ to distributions of other 
CWD-positive deer, but not non-CWD deer $(P \geq 0.778)$. The lone exception was the single CWD-positive deer from Stallion Range Center, whose distribution was not related to other CWD-positive deer or all other mule deer in general $(P \geq 0.667)$.

\section{DISCUSSION}

Chronic wasting disease was at most a minor direct mortality factor in the SAM, with annual mortality rates $\leq 0.01$ (or $\leq 0.02$ if censored individuals were classed as mortalities immediately following capture or at culling). Prevalence data suggested a similar impact. Maximum potential annual mortality from CWD based on the highest annual prevalence we observed (9\%) and a disease duration of two or three would be 0.05 and 0.03 , respectively. All of these rates would be less than the mortality rates of mule deer due to senescence alone (approximately $0.08-0.10$ based on a 12 or 10 year lifespan). Moreover, average annual mortality of radio-collared mule deer in the SAM was 0.19 for adult females and 0.16 for adult males (Bender et al., 2012). Thus, CWD-specific mortality rate (including censored deer) accounted for only $6 \%$ (males) to $11 \%$ (females) of observed mean annual mortality. Using prevalence data and assuming a typical $2-3$ y disease duration, maximum potential mortality in the SAM $(0.03-0.05)$ was $\leq 16-26 \%$ (females) or $\leq 19-31 \%$ (males) of the total observed mortality of mule deer. Level of adult mortality was not limiting population growth of mule deer in the SAM (Hoenes, 2008; Bender et al., 2012), and adult survival was higher than seen in other populations in arid New Mexico (Bender et al., 2011, 2012). Thus, effects of CWD on population-level mortality of deer were not resulting in any significant impacts on population rate of increase given observed prevalence. This was seen despite an older population age structure due to minimal harvesting and relatively low productivity (Hoenes, 2008; Bender et al., 2012).

Previously, CWD was shown to predispose mule deer to other mortality factors, including deervehicle collisions (Krumm et al., 2005) and puma predation (Krumm et al., 2010). Predisposition likely results from poor nutritional condition or lack of environmental awareness as the disease progresses (Williams et al., 2001). In the SAM, one CWD-positive female had her cause-of-death classified as unknown-not predation (Bender et al., 2012) approximately six months after testing positive at capture. She was not severely emaciated at death and was in better condition than the average lactating female at capture the previous autumn (percent ingesta-free body fat $=6.0 \% \mathrm{v}$. a mean of $5.1 \%$ [SE $=0.2$ ] for lactating females; L. Bender, unpublished data). Similarly, of 28 post-mortem tests, one puma-killed female subsequently tested positive for CWD. This female was extremely emaciated (femur marrow fat $<20 \%$; Cook et al., 2001, L. Bender, unpublished data) at death, indicating a high degree of predisposition to mortality. Our results therefore at least partially support CWD predisposing deer to other mortality factors, and thus mortality from CWD is likely compensatory to some degree (Krumm et al., 2010).

Chronic wasting disease was rare in the SAM and deer densities were much lower than in other sites where CWD is present, characteristics which make sustaining a CWD epidemic less likely (Miller et al., 2006). Most (92\%) CWD-positive deer were located in either the White Sands Main Post area, a residential development, or the Dripping Springs Recreation Area, both high human-use areas. Results from Colorado also found higher prevalence associated with developed habitats (Farnsworth et al., 2005). Deer associated with human developments tend to be tamer, have higher population densities, and are frequently present at water sites, feeders, and other concentration areas, which increases the likelihood of close contact and potentially disease transmission (Farnsworth et al., 2005; Miller et al., 2006, 2008). Because CWD prions can be transferred via saliva (Mathiason et al., 2006), excreta (Miller et al., 2006; Gultekin et al., 2009), and other tissues, deer in these areas may be more likely to be exposed because of higher frequency of contact with infectious prions, resulting in a positive association of CWD and human-developed areas. Similarly, because developed areas can act as refugia from hunting, deer often show older age structure in such areas, which further increases the opportunity for exposure to CWD (Farnsworth et al., 2005). 
The spatial distribution of disease can be related to the distribution or movement patterns of hosts or vectors (Conner \& Miller, 2004). For mule deer, potential movements hypothesized to spread CWD among populations include seasonal migrations, dispersal of juveniles, and dispersal or other long range movements of adults (such as movements of adult males during the rut) (Conner \& Miller, 2004; Conner et al., 2007). No radio-collared deer emigrated from the SAM during our study, and maximum spread of movements was $<20 \mathrm{~km}$, indicating that deer movements were localized. Similarly, no radio-tagged juveniles that survived through age 1.5 emigrated from the SAM and all remained within or adjacent to their maternal home range (Fig. 1). Because dispersal of juveniles is the most common means of long-range movement among populations of deer (Kie \& Czech, 2000), dispersal of juveniles would be a likely mechanism for spread of CWD from the SAM to adjacent habitats. However, work in Colorado suggested that migratory movements were more likely to spread CWD among populations than was dispersal (Conner $\&$ Miller, 2004). Further, prevalence of CWD is more common in older deer due to increased exposure time (Farnsworth et al., 2005), and thus juveniles show lower prevalence in part because they are exposed to infective deer or other infectious material for a short time prior to dispersal and the slow progression of the disease in individuals (Williams et al., 2001, 2002). Mule deer in the SAM are non-migratory, and lack of migratory movements in combination with the lack of dispersal indicates that the likelihood of spread of CWD to adjacent populations was low.

It is possible albeit unlikely that deer from other populations move to the SAM and return to their original ranges. Given the large proportion of radio-collared deer in areas associated with CWD in the SAM (at times approximately 50\% of the local deer) and the timing of captures (December and April), if such movements occurred during the most likely biological period (i.e., the rut in December), it is highly probable that some of these deer would have been captured and these movements seen as a dispersal from the SAM. Conner and Miller (2004) hypothesized that epidemics of CWD may be more rapid in populations where deer are sedentary and have small home ranges, noting that prevalence of CWD rose to $>50 \%$ in a captive population in $<7$ years. Mule deer in the SAM are sedentary, patchily distributed, and show small home ranges (females $=8-16 \mathrm{~km}^{2}$, males $=11-33 \mathrm{~km}^{2}$ ) (Hoenes, 2008; Bender et al., 2012), and thus fit this hypothesis. Further, distributions of CWD-positive deer in the SAM were strongly spatially correlated, similar to results from Wisconsin which showed that probability of infection was related to numbers of nearby infected deer (Grear et al., 2010). However, prevalence of CWD in the SAM did not increase over time (Table 1), indicating that free-ranging deer may not be predisposed to a significant population impact simply because of small, sedentary ranges. The low and stable prevalence of CWD in the SAM may be due to the low population density and patchy distribution of deer. Miller et al. (2006) suggested that CWD epidemics may not be sustained in areas where $<200$ deer comprised a wintering (i.e., close geographic proximity) group. Additionally, high clay content of soils may enhance the environmental persistence and infectivity of prions (Almberg et al., 2011; Walter et al., 2011). Clay content of soils in CWD areas of the SAM is low (primarily Nickel [ $<15 \%$ clay]-Upton [15-30\% clay] associations or rock outcrops; Bulloch \& Neher, 1980), which may limit environmental accumulation of prions. The combination of low deer densities, patchy deer distribution, and poor edaphic characteristics for prion accumulation likely contributed to observed trends in prevalence of CWD in the SAM. These characteristics are also typical of most mule deer populations in the arid Southwestern USA and Mexico (Galindo-Leal, 1993; Sánchez-Rojas \& Gallina, 2000; Esparza-Carlos et al., 2011; Bender et al., 2011, 2012).

The single exception to a contagious distribution of CWD-positive deer in the SAM was the single CWD-positive female from the Stallion Range Center. The range of this individual was well separated from other CWD-positive deer (Fig. 1). This disjunct occurrence highlights the uncertainty over mode of transmission or infection with CWD as no other individuals in this small subpopulation ( $<50$ deer) tested positive, despite 32 tonsillar biopsies performed at capture and several post-mortem samples. 


\section{CONCLUSIONS}

Prevalence and mortality data show that CWD had little population-level effect on mule deer in the SAM, likely because of low deer density, patchy distribution, and soil characteristics that do not favor accumulation or infectivity of prions, characteristics that are typical of mule deer populations in the Chihuahuan Desert habitats (Galindo-Leal,1993; Sánchez-Rojas \& Gallina, 2000; Esparza-Carlos et al., 2011; Bender et al., 2012). This was reflected in growth of the mule deer population, which more than doubled (an average increase of $>13 \%$ annually) from 2007 to 2014 in areas surveyed originally in 2007 (Bender et al., 2012; L. Bender, unpublished data). Because transmission of CWD is at least partially indirect, culling has been ineffective in controlling CWD (Conner et al., 2007) and annual removals may need to exceed $45 \%$ of the deer population to control CWD (Miller et al., 2006). Such a level of removal would quickly eliminate mule deer from many arid Southwestern habitats, given the relatively low deer density and productivity seen in mule deer populations in arid environments (Galindo-Leal, 1993; SánchezRojas \& Gallina, 2000; Lomas \& Bender, 2007; Bender et al., 2011, 2012). Culling would also only lower CWD prevalence, not eliminate CWD (Wasserberg et al., 2009). Consequently, culling mule deer to manage CWD would likely be ineffective unless the population was exterminated in the SAM or similar populations, and prions did not persist in the environment. Further, the low prevalence of CWD in the SAM (approximately $2.5 \%$ over time) suggests that CWD in other areas of the Southwest could well be present, because low prevalence makes detection difficult. This was corroborated by detection of CWD-positive deer and elk in the southern and central Sacramento Mountains, a distance of $\geq 65 \mathrm{~km}$ from the nearest location of a CWD-positive deer in the SAM.

ACKNOWLEDGements. We thank the U.S. Department of Defense-White Sands Missile Range, U.S. Fish and Wildlife Service-San Andres National Wildlife Refuge, U.S. Bureau of Land Management-Las Cruces Field Office, New Mexico Department of Game and Fish, and U.S. Geological Survey for funding this project. The New Mexico State University, Agricultural Experiment Station and Cooperative Extension Service provided additional financial support. We thank J. Barnitz, A. Bennett, K. Cobble, and K. Mower for field and logistical assistance. We thank D. Childress, R. Bodwin, and E. Watters for flight support for capture and surveys. All activities were in compliance with NMSU IACUC \# 2003-023 and 2009-205.

\section{LITERATURE CITED}

Almberg, E. S., Cross, P. C., Johnson, C. J., Heisey, D. M., Richards, B. J. (2011) Modeling routes of chronic wasting disease transmission: environmental prion persistence promotes deer population decline and extinction. PLOS One, 6 (5), e19896.

Bender, L. C., Hoenes, B. D., Rodden, C. L. (2012) Factors influencing survival of desert mule deer in the greater San Andres Mountains, New Mexico. Human-Wildlife Interactions, 6, 245-260.

Bender, L.C., Boren, J. C., Halbritter, H., Cox, S. (2011) Condition, survival, and productivity of mule deer in semiarid grassland-woodland in east-central New Mexico. Human-Wildlife Interactions, 5, $276-286$.

Bulloch, H. E. Jr., Neher, R. E. (1980) Soil survey of Dona Ana County area, New Mexico. U.S. Department of Agriculture, Soil Conservation Service, Washington DC.

Conner, M. M., Miller, M. W. (2004) Movement patterns and spatial epidemiology of a prion disease in mule deer population units. Ecological Applications, 14, 1870-1881.

Conner, M. M., Miller, M. W., Ebinger, M. R., Burnham, K. (2007) A meta-BACI approach for evaluating management intervention on chronic wasting disease in mule deer. Ecological Applications, 17, 140-153. 
Cook, R. C., Cook, J. G., Murray, D. L., Zager, P., Gratson, M. W. (2001) Development of predictive models of nutritional condition for Rocky Mountain elk. Journal of Wildlife Management, 65, 973-987.

Esparza-Carlos, J. P., Laundré, J., Sosa. V. (2011) Precipitation impacts on mule deer habitat use in the Chihuahuan Desert of Mexico. Journal of Arid Environments, 75, 1008-1015.

Farnsworth, M. L., Wolfe, L., Hobbs, N., Burnham, K., Williams, E., Theobald, D., Conner, M., Miller, M. (2005) Human land use influences chronic wasting disease prevalence in mule deer. Ecological Applications, 15, 119-126.

Galindo-Leal, C. (1993) Densidades poblacionales de los venados cola blanca, cola negra y bura en Norteamérica, pp. 371-391 In: Medellín, R. A., Ceballos, G. (Eds.). Avances en el Estudio de los Mamíferos de México. Asociación Mexicana de Mastozoología AC, México.

Grear, D. A., Samuel, W., Scribner, K., Weckworth, B., Langenberg, J. (2010) Influence of genetic relatedness and spatial proximity on chronic wasting disease infection among female white-tailed deer. Journal of Applied Ecology, 47, 532-540.

Gultekin, T., Miller, M., Wolfe, L., Sirochman, T., Glidden, D., Palmer, C., Lemus, A., DeArmond, S., Prusiner, S. (2009) Asymptomatic deer excrete infectious prions in faeces. Nature, 461, 529532.

Heisey, D. M., Fuller, T. K. (1985) Evaluation of survival and cause-specific mortality rates using telemetry data. Journal of Wildlife Management, 49, 668-674.

Heffelfinger, J. (2006) Deer of the Southwest: a complete guide to the natural history, biology, and management of Southwestern mule deer and white-tailed deer. Texas A\&M University, College Station, TX.

Hoenes, B. (2008) Identification of factors limiting desert mule deer populations in the greater San Andres Mountains of southcentral New Mexico. M.S. Thesis. New Mexico State University, Las Cruces, NM.

Kie, J. G., Czech, B. (2000) Mule and black-tailed deer, pp. 629-657 In: Demarais S., Krausman, P. (Eds.). Ecology and management of large mammals in North America. Prentice-Hall, Upper Saddle River, NJ.

Krumm, C. E., Conner, M., Miller, M. (2005) Relative vulnerability of chronic wasting disease infected mule deer to vehicle collisions. Journal of Wildlife Management, 41, 503-511.

Krumm, C. E., Conner, M., Hobbs, N., Hunter, D., Miller, M. (2010) Mountain lions prey selectively on prion-infected mule deer. Biology Letters, 6, 209-211.

Little, J. M., Berrens, R. P. (2008) The Southwestern market for big-game hunting permits and services: a hedonic pricing analysis. Human Dimensions of Wildlife, 13, 143-157.

Lomas, L. A., Bender, L. C. (2007) Survival and cause-specific mortality of mule deer fawns in northcentral New Mexico. Journal of Wildlife Management, 71, 884-894.

Mathiason, C. K., Powers, J., Dahmes, S., Osborn, D., Miller, K., Warren, R., Mason, G., Hays, S., Hayes-Klug, J., Seelig, D., Wild, M., Wolfe, L., Spraker, T., Miller, M., Sigurdson, C., Telling, G., Hoover, E. (2006) Infectious prions in the saliva and blood of deer with chronic wasting disease. Science, 314, 133-136.

Miller, M. W., Williams, E. S. (2002) Detection of PrP ${ }^{\mathrm{CWD}}$ in mule deer by immunohistochemistry of lymphoid tissues. Veterinary Record, 151, 610-612.

Miller, M. W., Hobbs, N, Tavener, S. (2006) Dynamics of prion disease transmission in mule deer. Ecological Applications, 16, 2208-2214.

Miller, M. W., Williams, E., Hobbs, N., Wolfe, L. (2004) Environmental sources of prior transmission in mule deer. Emerging Infectious Diseases, 10, 1003-1006.

Miller, M. W., Swanson, H., Wolfe, L., Quartarone, F., Huwer, S., Southwick, C., Lukacs, P. (2008) Lions and prions and deer demise. PLOS One, 6, e4019.

Muldavin, E., Chauvin, Y., Harper, G. (2000) The vegetation of White Sands Missile Range, New Mexico. Vol. 1-2: Handbook of vegetation communities. Final report for cooperative agreement 
no. 14-16-002-91-233. White Sands Missile Range, U.S. Fish and Wildlife Service, The Nature Conservancy, and the University of New Mexico, WSMR, NM.

Potapov, A. E., Merrill, E., Pybus, D., Coltman, D., Lewis, M. (2013) Chronic wasting disease: possible transmission mechanisms in deer. Ecological Modelling, 250, 244-257.

Sánchez-Rojas, G., Gallina, S. (2000) Mule deer (Odocoileus hemionus) density in a landscape element of the Chihuahuan Desert, Mexico. Journal of Arid Environments, 44, 357-368.

Saunders, S. E., Bartelt-Hunt, S., Bartz, J. (2012) Occurrence, transmission, and zoonotic potential of chronic wasting disease. Emerging Infectious Diseases, 18, 369-376.

Slauson, W. L., Cade, B., Richards, J. (1991) User manual for BLOSSOM statistical software. U.S. Geological Survey, National Ecology Research Center, Ft. Collins, CO.

Walter, W. D., Walsh, D., Farnsworth, M., Winkelman, D., Miller, M. (2011) Soil clay content underlies prion infection odds. Nature Communications, 2, 200.

Wasserberg, G., Osnas, E., Rolley, R., Samuel, M. (2009) Host culling as an adaptive management tool for chronic wasting disease in white-tailed deer: a modeling study. Journal of Applied Ecology, 46, 457-466.

Williams, E. S., Kirkwood, J., Miller, M. (2001) Transmissible spongiform encephalopathies, pp. 292301 In: Williams, E. S., Barker, I. K. (Eds.). Infectious diseases of wild mammals. Iowa State University Press, Ames, IA.

Williams, E. S., Miller, M., Kreeger, T., Kahn, R., Thorne, E. (2002) Chronic wasting disease of deer and elk: a review with recommendations for management. Journal of Wildlife Management, 66, 551-563.

Wolfe, L. L., Conner, M., Baker, T., Dreitz, V., Burnham, K., Williams, E., Hobbs, N., Miller, M. (2002) Evaluation of antemortem sampling to estimate chronic wasting disease prevalence in freeranging mule deer. Journal of Wildlife Management, 66, 564-573.

Zar, J. H. (1996) Biostatistical analysis. Prentice Hall, Upper Saddle River, NJ. 